\title{
Basic characteristics of Australian iron ore concentrate and its effects on sinter properties during the high-limonite sintering process
}

\author{
Dong-hui Liu ${ }^{1)}$, Hao Liu ${ }^{2)}$, Jian-liang Zhang ${ }^{1)}$, Zheng-jian Liu ${ }^{1)}$, Xun Xue ${ }^{1,3)}$, Guang-wei Wang ${ }^{1)}$, \\ and Qing-feng Kang ${ }^{1)}$ \\ 1) School of Metallurgy and Ecological Engineering, University of Science and Technology Beijing, Beijing 100083, China \\ 2) Xuanhua Iron \& Steel Group Co. Ltd., Xuanhua 075100, China \\ 3) Beijing Shenwu Environment \& Energy Technology Co., Ltd., Beijing 102200, China \\ (Received: 23 March 2017; revised: 3 May 2017; accepted: 5 May 2017)
}

\begin{abstract}
The basic characteristics of Australian iron ore concentrate (Ore-A) and its effects on sinter properties during a high-limonite sintering process were studied using micro-sinter and sinter pot methods. The results show that the Ore-A exhibits good granulation properties, strong liquid flow capability, high bonding phase strength and crystal strength, but poor assimilability. With increasing Ore-A ratio, the tumbler index and the reduction index (RI) of the sinter first increase and then decrease, whereas the softening interval $(\Delta T)$ and the softening start temperature $\left(T_{10 \%}\right)$ of the sinter exhibit the opposite behavior; the reduction degradation index $\left(\mathrm{RDI}_{+3.15}\right)$ of the sinter increases linearly, but the sinter yield exhibits no obvious effects. With increasing Ore-A ratio, the distribution and crystallization of the minerals are improved, the main bonding phase first changes from silico-ferrite of calcium and aluminum (SFCA) to kirschsteinite, silicate, and SFCA and then transforms to $2 \mathrm{CaO} \cdot \mathrm{SiO}_{2}$ and SFCA. Given the utilization of Ore-A and the improvement of the sinter properties, the Ore-A ratio in the high-limonite sintering process is suggested to be controlled at approximately $6 \mathrm{wt} \%$.
\end{abstract}

Keywords: iron ore concentrate; limonite; basic characteristics; sinter properties; sintering process

\section{Introduction}

Twenty-two large-scale blast furnaces (BFs) larger than $4000 \mathrm{~m}^{3}$ are currently operating in China. With the rapid development of high-grade burden and large-scale BFs, sinter plays an increasingly important role in determining the operating conditions of BFs. However, the current status of the iron and steel market is weak; high production costs have become the main obstacle for the survival and development of steel enterprises [1-3]. Therefore, reducing production costs has become the primary task for the sustainable development of metallurgical processes.

To reduce production costs and promote sustainable development in the steel industry, low-priced limonite has been used by steel enterprises for sintering production. For example, the limonite usage ratio in the sinter mixture for some steel enterprises such as Baosteel has reached 50 wt\%.
Many researchers have focused on the sintering behavior of limonite and its effect on the properties of sinter. Their results have indicated that limonite has a high crystal water (CW) content and that its use results in more pores after sintering, leading to a high sintering velocity and a long holding time at high temperatures, which in turn results in insufficient minerals crystallization [4-6]. In addition, the usage of limonite easily results in a poor temperature control melt; thus, the pores in the sinter do not have sufficient time to densify, leading to a thin bonding layer of the melt, all of which adversely affects the sinter strength and increases production costs [7-11].

Regarding to the aforementioned drawbacks of limonite, given the complementarity principle of iron ores' basic characteristics and with the objective of improving the sinter properties, magnetite iron ore concentrate should be added in high-limonite-proportion sintering processes. Australian 
iron ore concentrate is a magnetite concentrate characterized by being inexpensive and present in abundant reserves. The estimated reserves of the Australian iron ore concentrate are 35 billion tons, which accounts for $20.6 \mathrm{wt} \%$ of the world iron ore reserves [12-14]. Therefore, the reasonable utilization of Australian iron ore concentrate in high-limonite sintering processes not only improves sinter properties but also reduces production costs, which is a promising development direction for sinter production.

\section{Experimental}

\subsection{Materials and sample preparation}

Return fines, a mixed material, and eight iron ores were used as iron-bearing materials; quickened lime and coke breeze were also used as sintering raw materials in the present research. The chemical composition of the raw materials is listed in Table 1. The X-ray diffraction (XRD) pattern of the Australian iron ore concentrate (Ore-A) is shown in Fig. 1.

Table 1. Chemical composition of the iron-bearing materials

\begin{tabular}{ccccccc}
\hline Material & \multicolumn{1}{c}{$\mathrm{TFe}$} & $\mathrm{CaO}$ & $\mathrm{SiO}_{2}$ & $\mathrm{MgO}$ & $\mathrm{Al}_{2} \mathrm{O}_{3}$ & \multicolumn{1}{c}{$\mathrm{LOI}$} \\
\hline Ore-A & 64.97 & 0.19 & 8.54 & 0.48 & 0.20 & -2.27 \\
Ore-B & 66.20 & 0.36 & 4.40 & 0.40 & 0.10 & -0.50 \\
Ore-C & 66.65 & 0.48 & 1.90 & 2.15 & 0.31 & -2.00 \\
Ore-D & 61.60 & 0.02 & 3.45 & 0.06 & 2.30 & 5.90 \\
Ore-E & 57.46 & 0.01 & 5.50 & 0.06 & 1.28 & 11.57 \\
Ore-F & 63.60 & 0.01 & 4.40 & 0.02 & 1.80 & 2.82 \\
Ore-G & 61.50 & 0.08 & 3.90 & 0.07 & 2.30 & 2.20 \\
Ore-H & 60.79 & 0.02 & 9.88 & 0.10 & 1.00 & 2.30 \\
Return fines & 57.00 & 8.60 & 5.10 & 1.40 & 1.90 & 0.50 \\
Mixed ma- & 41.83 & 11.92 & 1.90 & 6.98 & 0.63 & 15.51 \\
terial & & 1.35 & 6.00 & 0.38 & 4.50 & 85.00 \\
Coke breeze & - & & & & & \\
Quickened & - & 79.00 & 3.00 & 1.00 & 4.80 & 7.00 \\
lime & & & & & &
\end{tabular}

Note: LOI-Loss on ignition.

Table 1 and Fig. 1 show that Ore-A is a typical Australian magnetite concentrate with a comparatively high $\mathrm{SiO}_{2}$ content and a high iron grade. Ore-B and Ore- $\mathrm{C}$ are magnetite concentrates, and Ore- $\mathrm{C}$ has the highest iron content among the iron-bearing materials used in this work. The iron grades of the other iron ores are lower than $64 \%$, and the return fines from $\mathrm{BF}$ sieving exhibits the lowest iron content. Ore-D and Ore-E are typical limonite ores with high CW contents. Ore-F, Ore-G, and Ore-H are Brazilian hematite ores with comparatively high iron grades $(63.60 \%, 61.50 \%$, and $60.79 \%$, respectively). Ore-A and Ore-H have high $\mathrm{SiO}_{2}$ contents, whereas Ore-D and Ore-E have high CW contents; all of these ores should be reasonably used in combination with other iron ores because of their poor sintering properties.

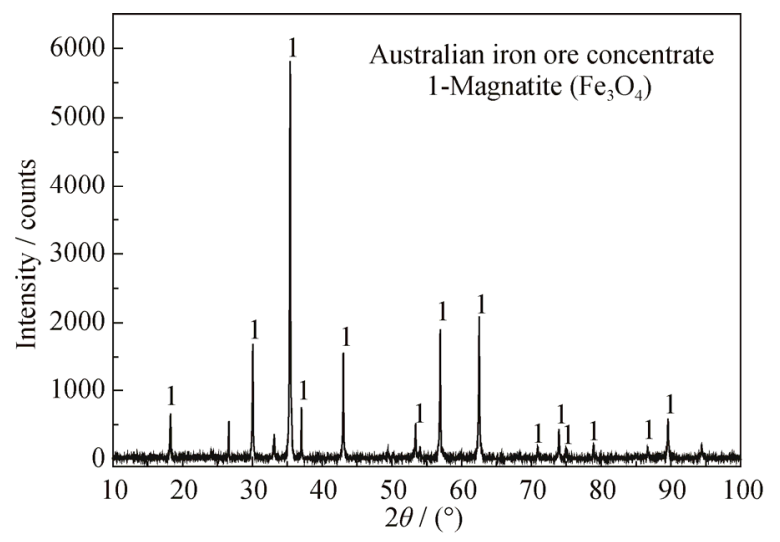

Fig. 1. XRD pattern of the Australian iron ore concentrate.

Australian iron ore concentrate is the main studied material in this work. The granulation property of a sinter mixture is mainly influenced by the particle size distribution and mineralogical appearance of its iron-bearing components. The particle size distribution and mineralogical appearance of the Australian iron ore concentrate are shown in Fig. 2. The particle size of the Australian iron ore concentrate ranges from 0.1 to $1000 \mu \mathrm{m}$, and its mean particle size is $15.045 \mu \mathrm{m}$. The mean particle size of the Australian iron ore concentrate is comparatively small, and its particles are mostly irregularly shaped spheres; the particle surface is comparatively coarse and large numbers of small fine particles are adhered to it. Therefore, the Australian iron ore concentrate is beneficial for granulation.

\subsection{Experimental methods}

\subsubsection{Basic characteristics}

To clarify the high temperature behavior of Australian iron ore concentrate in the sintering process, four tests [3] including assimilability, liquid fluidity, bonding phase strength, and crystal strength [8] were carried out using the micro-sinter equipment.

The Australian iron ore concentrate was dried at $105^{\circ} \mathrm{C}$ for $3 \mathrm{~h}$ and ground to a particle size less than $147 \mu \mathrm{m}$. In the measurement of assimilability, the iron ore was compacted into a cylinder of $5 \mathrm{~mm}$ high and $8 \mathrm{~mm}$ in diameter at 15 $\mathrm{MPa}$ for $2 \mathrm{~min}$, and pure $\mathrm{CaO}$ was pressed into a cylinder of $5 \mathrm{~mm}$ high and $20 \mathrm{~mm}$ in diameter at $20 \mathrm{MPa}$ for $2 \mathrm{~min}$. In sequence, the cylinder of iron ore was placed over the cylinder of pure $\mathrm{CaO}$ and sintered in the micro-sinter equipment. The room temperature and experimental temperature are expressed as RT and ET, respectively. The heating curve 

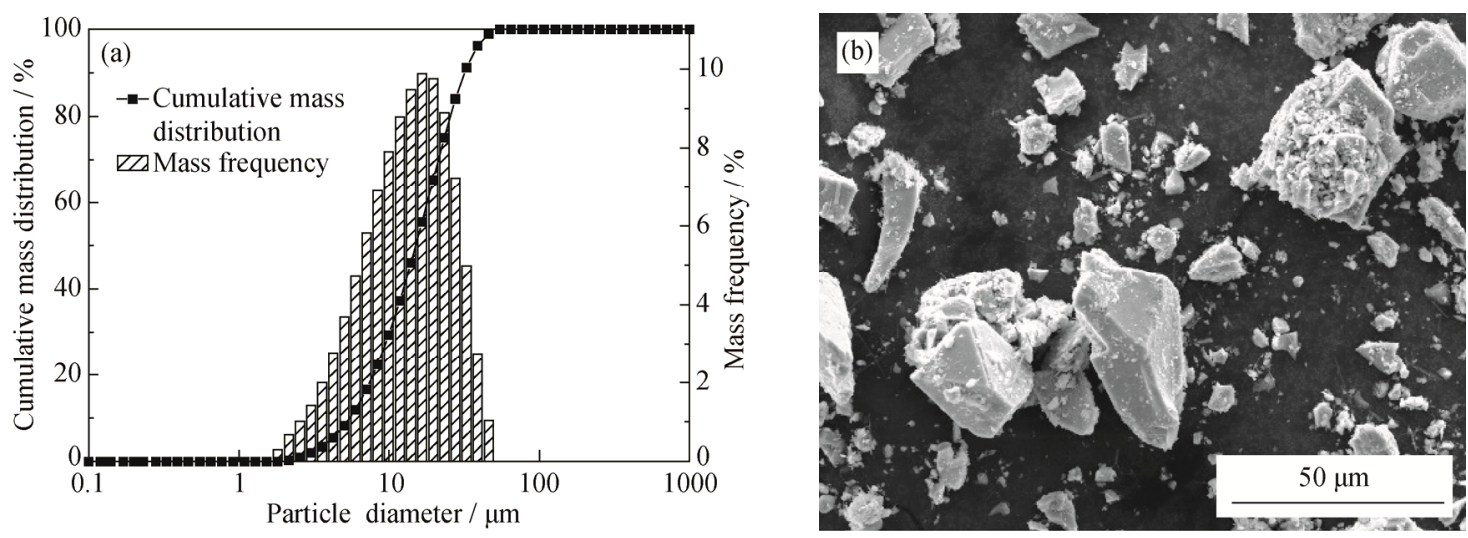

Fig. 2. Particle size distribution (a) and mineralogical microstructure (b) of the Australian iron ore concentrate.

Table 2. Heating rate and atmosphere of the assimilability tests

\begin{tabular}{ccccc}
\hline Temperature & $\mathrm{RT}-600^{\circ} \mathrm{C}$ & $600-1000^{\circ} \mathrm{C}$ & $1000-1050^{\circ} \mathrm{C}$ & $1050^{\circ} \mathrm{C}-\mathrm{ET}$ \\
Time $/$ min & 4 & 1 & Air (The gas flow is $3 \mathrm{~L} / \mathrm{min}$ ) & 1 \\
Atmosphere & & $\mathrm{ET}-1050^{\circ} \mathrm{C}$ & $1050-1000^{\circ} \mathrm{C}$ & $1000^{\circ} \mathrm{C}-\mathrm{RT}$ \\
Temperature & $\mathrm{ET}$ & 2 & 1.5 & Natural cooling \\
Time $/$ min & 4 & Air (The gas flow is 3 L/min) & \\
Atmosphere & & & & \\
\hline \hline
\end{tabular}

and experimental atmosphere of the assimilability tests are listed in Table 2. The lowest assimilation temperature (LAT) is expressed as the temperature at which the material starts to assimilate.

In the measurements of crystal strength, bonding phase strength, and liquid fluidity, the selected materials were Australian iron ore concentrate and a fine mixture of Australian iron ore concentrate and $\mathrm{CaO}$ pure reagent (the binary basicity of the fine mixtures was 2.0 and 4.0, respectively); the three selected materials were respectively pressed into a cylinder with a height of $5 \mathrm{~mm}$ and a diameter of $8 \mathrm{~mm}$ at $15 \mathrm{MPa}$ for $2 \mathrm{~min}$ and sintered in the micro-sinter equipment. The cylinder preparation procedure and heating curve were the same as those used in the assimilability tests. The experimental temperature was set to $1280^{\circ} \mathrm{C}$, the experimental atmosphere from $600^{\circ} \mathrm{C}$ to the experimental temperature (after the temperature was maintained for $4 \mathrm{~min}$ ) was $\mathrm{N}_{2}$; the other steps were carried out under air, and the gas flows of air and $\mathrm{N}_{2}$ were maintained at $3 \mathrm{~L} / \mathrm{min}$.

After the sintered samples cooled to room temperature, the first two sintered samples were placed on the platform of a pressure-testing device for the measurement of their crystal strength and bonding phase strength, and the vertical projection area of the melt formed by the third sintered sample was measured using an analytical imaging method.
The formula used to calculate the fluidity index is shown in Eq. (1):

Fluidity index $=\frac{S_{\text {after }}-S_{\text {before }}}{S_{\text {before }}}$

where $S_{\text {before }}$ is the vertical projection area of the third sintered sample before the test $\left(\mathrm{mm}^{2}\right)$ and $S_{\text {after }}$ is the vertical projection area of the melt after the test $\left(\mathrm{mm}^{2}\right)$. All of the tests were performed three times for each scheme, and the average value was used.

\subsubsection{Sinter pot tests}

To clarify the effects of Australian iron ore concentrate on the properties of sinter with a high proportion of limonite, sinter pot tests and sinter properties tests were conducted. All of the tests were performed twice and the average value was used. The sinter pot tests were carried out in a sinter pot with an inner diameter of $350 \mathrm{~mm}$. The sinter mixture was controlled at $80 \mathrm{~kg}$, the thickness of the sintering bed was $700 \mathrm{~mm}$, the negative pressure of ignition was $7000 \mathrm{~Pa}$, the ignition temperature was $1100^{\circ} \mathrm{C}$, the ignition time was $1.5 \mathrm{~min}$, and the negative pressure of sintering was $15000 \mathrm{~Pa}$. The sinter pot tests were stopped when the sintering exhaust gas temperature began to decrease. The ratio of blending ores and return fines from sintering sieving were $77.10 \mathrm{wt} \%$ and $8.5 \mathrm{wt} \%$, respectively. The moisture, basicity, and fixed carbon content of the sinter mixture were controlled at approximately $8.5 \mathrm{wt} \%, 1.88$, and $3.3 \mathrm{wt} \%$, respectively. 
The sinter tumbler test was based on standard GB/T5166 - 2005. The test of sinter reduction properties and low-temperature reduction degradation were based on standard GB/T13242-1991. The load used in the sinter softening tests was $1 \mathrm{~kg} / \mathrm{cm}^{2}$, and the crucible size used was $\phi 75 \mathrm{~mm} \times 200 \mathrm{~mm}$ (inner diameter $\times$ height). The particle size of the sinter and the coke in the sinter softening tests was $10-12.5 \mathrm{~mm}$, the weight of the sinter was $450 \mathrm{~g}$, and the weight of the coke was $20 \mathrm{~g}$; the coke particles were split into two equal parts, and sinter particles were placed between them. To characterize the softening behavior of the sinter, the temperature at which the shrinkage ratio of the sinter reached $10 \%$ was defined as the softening start temperature $\left(T_{10 \%}\right)$; the temperature at which the shrinkage ratio of the sinter reached $40 \%$ was defined as the softening end temperature $\left(T_{40 \%}\right)$; the softening interval $(\Delta T)$ is the difference between $T_{40 \%}$ and $T_{10 \%}$. The heating rate and atmosphere of the sinter softening test is shown in Fig. 3.

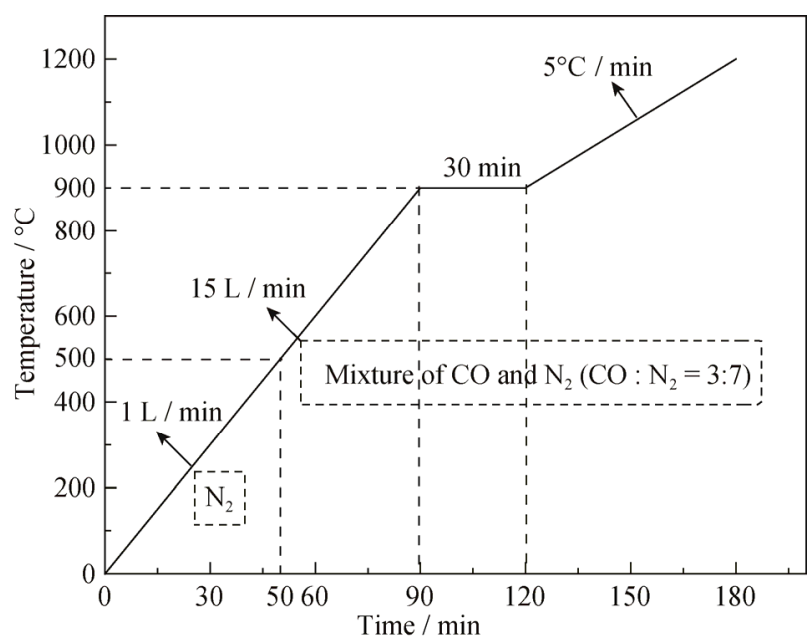

Fig. 3. Graphical presentation of the experimental atmosphere and the heating curve.

\section{Results and discussion}

\subsection{Basic characteristics of Australian iron ore concen- trate}

The iron ores' basic characteristics refer to their physical and chemical properties and behaviors in high-temperature processes, which are the basic indexes used to measure iron ores' contribution to sinter properties. Therefore, fully elucidating the iron ores' basic characteristics is important for understanding the sintering mechanism and improving the technical and economic target [15-16].

Assimilability refers to the reaction ability between iron ores and $\mathrm{CaO}$ during the sintering process, which reflects the degree of difficulty in generating a melt; it is expressed by the lowest assimilation temperature (LAT). Liquid fluidity is the melt flowing ability during the sintering process. It reflects the effective bonding range of the melt and is expressed as the liquid fluidity index (LFI). The bonding phase strength is the consolidative ability between the sintering liquid and the ore nuclei. The crystal strength represents the consolidative ability through crystal bond connections in the local area where a melt cannot be formed because of the basicity segregation of the sinter mixture.

The Australian iron ore concentrate's basic characteristics are shown in Table 3. The LAT of the Australian iron ore concentrate is $1340^{\circ} \mathrm{C}$, and its assimilation capability is comparatively low. The main mineral in Australian iron ore concentrate is $\mathrm{Fe}_{3} \mathrm{O}_{4}$; however, $\mathrm{Fe}_{3} \mathrm{O}_{4}$ cannot react with $\mathrm{CaO}$ directly, leading to a low assimilability and a high LAT. Many researches have indicated that an appropriate LFI is between 0.7 and 1.6. The LFI of the Australian iron ore concentrate is 1.36 , which means that the liquid flow capability is comparatively high. The Australian iron ore concentrate is magnetite characterized by a high $\mathrm{SiO}_{2}$ content; the amount of $\mathrm{CaO}$ added could be increased without changing the binary basicity of the fine mixture. In addition, the binary phase diagram of $\mathrm{CaO}-\mathrm{Fe}_{2} \mathrm{O}_{3}$ [17] shows that the superheat of the melt formed by magnetite is higher than that of other iron ores at the same temperature; as a result, the viscosity of the melt would be reduced. All of these factors can improve the ore's fluidity; thus, the liquid flow capability of the Australian iron ore concentrate is comparatively high.

Table 3. Basic characteristics of the Australian iron ore concentrate

\begin{tabular}{ccccc}
\hline Material & LAT $/{ }^{\circ} \mathrm{C}$ & LFI & $\begin{array}{c}\text { Bonding phase } \\
\text { strength } / \mathrm{N}\end{array}$ & $\begin{array}{c}\text { Crystal } \\
\text { strength } / \mathrm{N}\end{array}$ \\
\hline Ore-A & 1340 & 1.36 & 4126 & 6826 \\
\hline
\end{tabular}

The bonding phase strength and crystal strength of Australian iron ore concentrate are comparatively high: 4126 and $6826 \mathrm{~N}$, respectively. For the fine mixture of magnetite concentrate and $\mathrm{CaO}$ (the binary basicity is 2.0), the main minerals in the sintered body are high-strength $\mathrm{Fe}_{3} \mathrm{O}_{4}$ and the eutectic composed of $\mathrm{Fe}_{3} \mathrm{O}_{4}$ and fayalite. At the same time, a melt capable of high flow can make a compact sinter structure, resulting in a comparatively high bonding phase strength. Compared with hematite, the high-transfer-ability $\mathrm{Fe}_{2} \mathrm{O}_{3}$ crystallite can be easily generated at low temperatures during the magnetite sintering process; in this case, the growth rate of crystallite is comparatively faster, leading to high crystal strength. 


\subsection{Effects of Australian iron ore concentrate ratios on the sinter properties}

As previously mentioned, the Australian iron ore concentrate exhibits good granulation properties and liquid fluidity and high bonding phase strength and crystal strength, but poor assimilability. Given the complementarity principle of iron ores' basic characteristics and making full use of the Australian iron ore concentrate while improving the sinter properties, the schemes of ore proportioning tests were designed according to the present scheme of $0 \#$. The effects of the Australian iron ore concentrate ratios on the sinter properties were studied by adjusting the ratio of Ore-A in the mixed ores in increments of $3 \mathrm{wt} \%$. The schemes of the ore proportioning tests are listed in Table 4.

\subsubsection{Sinter strength}

Fig. 4 shows the effects of the Australian iron ore concentrate ratios on the sinter strength. The results in this figure indicate that the tumbler index of sinter and the ratio of 10-40 $\mathrm{mm}$ sinter first increase and then decrease with increasing Ore-A ratio, reaching a maximum $(68.33 \mathrm{wt} \%$ and
$75.26 \mathrm{wt} \%$, respectively) when the Ore-A ratio is $3 \mathrm{wt} \%$. However, few effects of the Australia iron ore concentrate on the sinter yield are observed.

Ore-A, Ore-C, and Ore-H exhibit good granulation property; however, Ore-B and Ore-D exhibit the opposite behavior. When the Ore-A ratio is increased from $0 \mathrm{wt} \%$ to $6 \mathrm{wt} \%$, the total ratio of Ore-C and Ore-H decreases from $14 \mathrm{wt} \%$ to $2 \mathrm{wt} \%$; however, the ratio of Ore-D increases from $14 \mathrm{wt} \%$ to $20.2 \mathrm{wt} \%$. Thus, the sintering velocity decreased, leading to the prolonging of the holding time at high temperatures and resulting in full crystallization of minerals and a compact sinter structure. However, with continuously increasing Ore-A ratio, the decreasing amplitude of Ore-B and the increasing amplitude of Ore-D are approximately the same; thus, the vertical sintering velocity of the sinter mixture with a high proportion of limonite evidently increases and the unmelted materials in the sintering bed do not have sufficient time to melt because of the short sintering holding time. As a result, effective bonding between adjacent nuclei ores is diminished, which adversely affects the sinter strength.

Table 4. Schemes of the ore proportioning tests

$\mathrm{wt} \%$

\begin{tabular}{ccccccccccc}
\hline Scheme & Ore-A & Ore-B & Ore-C & Ore-D & Ore-E & Ore-F & Ore-G & Ore-H & Ore-I \\
\hline $0 \#$ & 0 & 6 & 5.0 & 14.0 & 34.0 & 18.0 & 5.0 & 9.0 & 9.0 \\
$3 \#$ & 3 & 3.8 & 0.0 & 21.2 & 35.0 & 18.0 & 5.0 & 5.0 & 9.0 \\
$6 \#$ & 6 & 4.8 & 0.0 & 20.2 & 35.0 & 18.0 & 5.0 & 2.0 & 9.0 \\
$9 \#$ & 9 & 2.9 & 0.0 & 20.1 & 36.0 & 18.0 & 5.0 & 0.0 & 9.0 \\
$12 \#$ & 12 & 0.0 & 0.0 & 24.6 & 33.6 & 15.0 & 5.8 & 0.0 & 9.0 \\
\hline
\end{tabular}
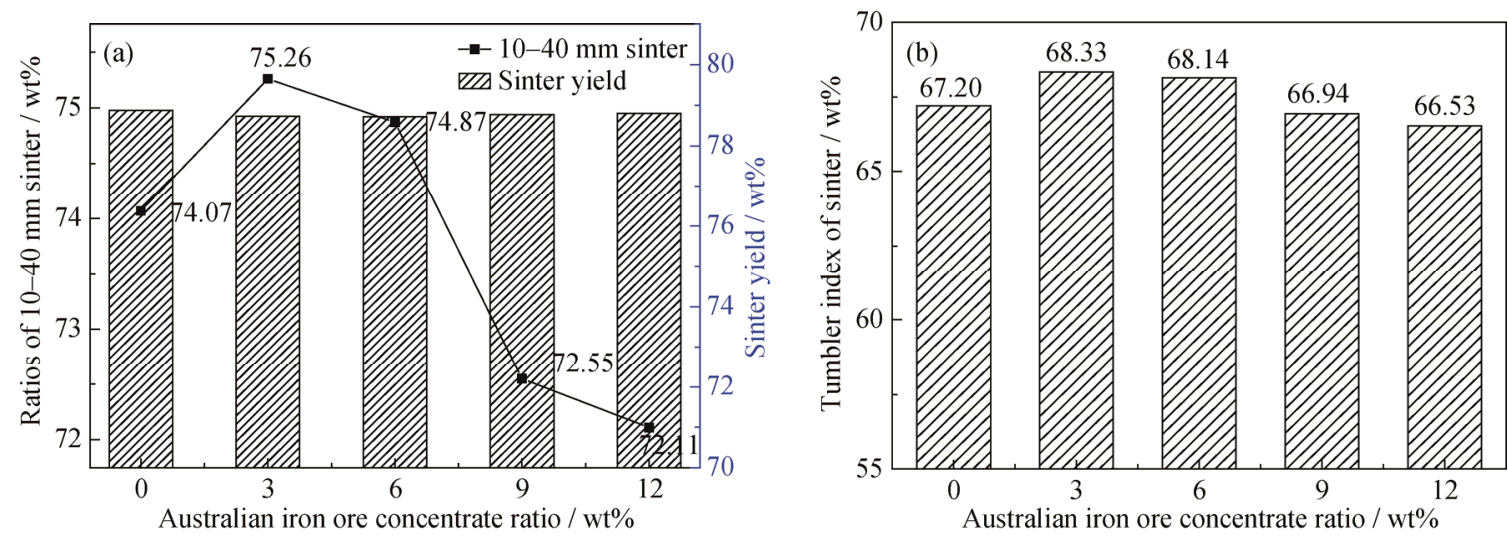

Fig. 4. (a) Effect of the Australian iron ore concentrate on sinter strength and ratios of $10-40 \mathrm{~mm}$ sinter and the sinter yeild; (b) effect of the Australian iron ore concentrate on the tumbler index of sinter.

\subsubsection{Sinter mineral composition and morphology}

The XRD analysis of sinter samples $0 \#, 6 \#, 9 \#$, and 12\# are shown in Fig. 5. The main compounds in the four sinter samples, as revealed by their XRD patterns, are hematite, magnetite, and calcium iron oxide. However, the chemical composition of calcium iron oxide for the four sinters differs, as detailed in the discussion of the scanning electron microscopy (SEM) analysis results. When the Ore-A ratio is $0 \mathrm{wt} \%$, the diffraction peak of the sinter is wide and disperse. As the Ore-A ratio is increased from $0 \mathrm{wt} \%$ to $6 \mathrm{wt} \%$, the diffraction peaks of the hematite increase in intensity and their full-widths at half-maxima become narrow, which in- 
dicates an increase in the degree of mineral crystallization. With continuously increasing Ore-A ratio, the diffraction peak of hematite in the sinter first decreases and then increases, whereas the magnetite exhibits the opposite behavior.

SEM and energy-dispersive X-ray spectroscopy were used to investigate the microstructure of sinter samples. Fig. 6 shows the mineralogical morphology of the sinter at various Australian iron ore concentrate ratios. As evident in the figure, when the Ore-A ratio is $0 \mathrm{wt} \%$, the main metal phases in the sinter are hematite, magnetite, and the interlaced corrosion structure minerals composed of hematite and magnetite. The main bonding phases in the sinter are needle-like and silico-ferrite of calcium and aluminum sheet (SFCA) and a spot of unreacted $\mathrm{CaO}$. The SFCA phase is distributed irregularly around pores and is interweaved by hematite to form an interlaced corrosion structure. The hematite distribution is uneven, and no bonding phase is observed among

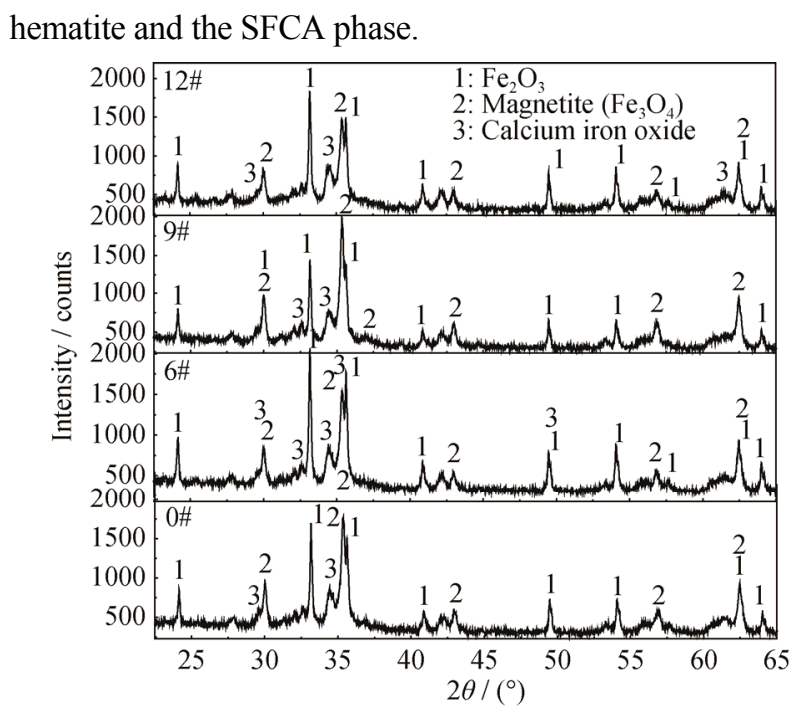

Fig. 5. X-ray diffraction patterns of sinter samples 0\#, 6\#, 9\#, and 12\#.
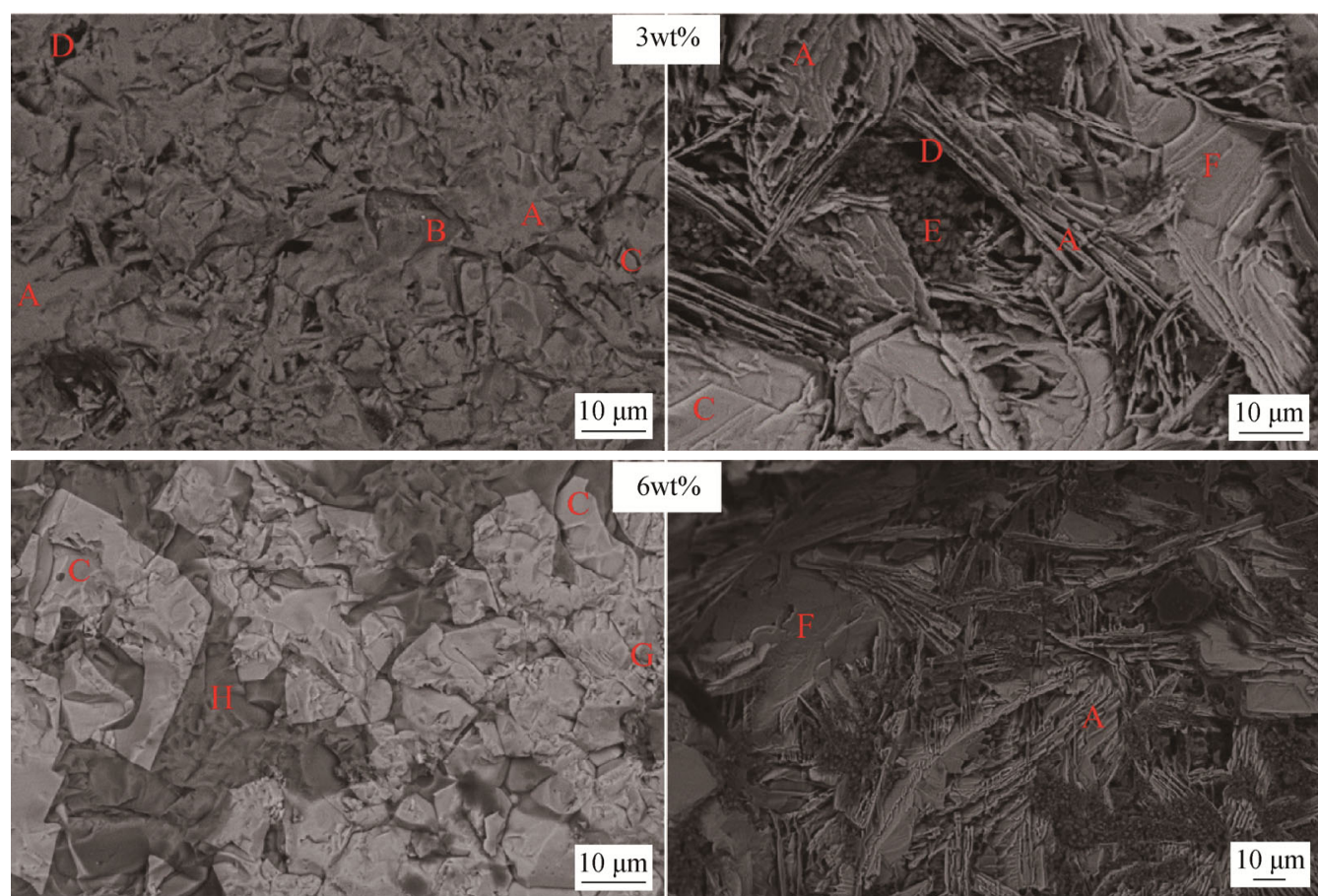

$6 \mathrm{wt} \%$

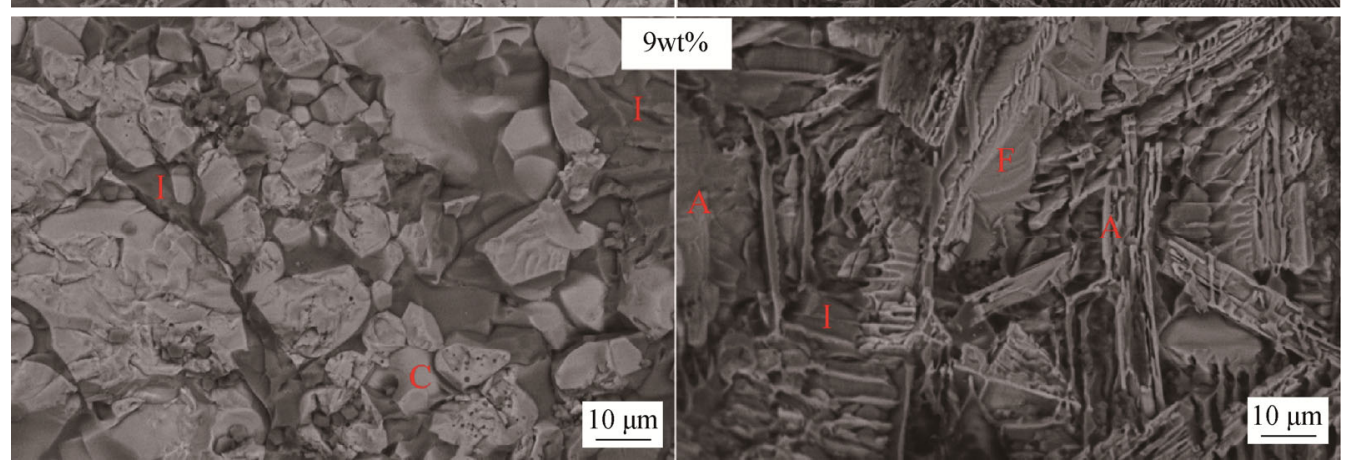

Fig. 6. Mineralogical morphology of the sinter at various Australian iron ore concentrate ratios (left: metal phase and parts of bonding phase; right: morphology of SFCA). A-SFCA; B-m $m \mathrm{Fe}_{2} \mathrm{O}_{3} \cdot n \mathrm{Fe}_{3} \mathrm{O}_{4} ; \mathrm{C}-\mathrm{Fe}_{2} \mathrm{O}_{3} ; \mathrm{D}-\mathrm{Pore} ; \mathrm{E}-\mathrm{CaO} ; \mathrm{F}-\mathrm{SFCA} \cdot \mathrm{mFe} \mathrm{O}_{3}$; $\mathrm{G}-\mathrm{Fe}_{3} \mathrm{O}_{4} ; \mathrm{H}-(\mathrm{CaO})_{x} \cdot(\mathrm{FeO})_{2}-x \mathrm{SiO}_{2} ; \mathrm{I}-2 \mathrm{CaO} \cdot \mathrm{SiO}_{2}$. 
When the Ore-A ratio is increased to $6 \mathrm{wt} \%$, the content of the interlaced corrosion structure minerals composed of hematite and magnetite in the sinter decreases. The mineral distribution is more even, and the crystallization is more sufficient. The main bonding phase changes from one kind of SFCA to kirschsteinite, silicate, and SFCA, and the kirschsteinite is mainly filled in hematite. When the Ore-A ratio is increased to $9 \mathrm{wt} \%$, the bonding phase transforms to $2 \mathrm{CaO} \cdot \mathrm{SiO}_{2}$ and SFCA and the SFCA content decreases. In addition, the minerals' distribution in the sinter is more uneven, the hematite is filled by $2 \mathrm{CaO} \cdot \mathrm{SiO}_{2}$ and magnetite, and most of the area is hematite and magnetite.

\subsubsection{Sinter metallurgical properties}

Fig. 7 shows the effects of the Australian iron ore concentrate ratios on the sinter metallurgical properties. The results in this figure indicate that the reduction index (RI) of the sinter first increases and then decreases with increasing Ore-A, whereas the $\Delta T$ of the sinter exhibits the opposite behavior. The RI and $\Delta T$ of the sinter range from $83.95 \%$ to $85.50 \%$ and from $88^{\circ} \mathrm{C}$ to $97^{\circ} \mathrm{C}$, respectively, which can fulfill the requirement for $\mathrm{BF}$ smelting. The reduction degradation index $\left(\mathrm{RDI}_{+3.15}\right)$ and $T_{10 \%}$ of the sinter are comparatively low $\left(60.5 \mathrm{wt} \%-63.35 \mathrm{wt} \%\right.$ and $1042-1055^{\circ} \mathrm{C}$, respectively). Overall, with increasing Ore-A ratio, the $\mathrm{RDI}_{+3.15}$ of the sinter increases linearly and the $T_{10 \%}$ of the sinter first decreases and then increases, except in the case of scheme $9 \#$.

When the Ore-A ratio is increased from $0 \mathrm{wt} \%$ to $6 \mathrm{wt} \%$, the sintering velocity decreases, which makes the low-melting point liquid more easily generated and the mineral crystallization more sufficient. Therefore, the RI and $\mathrm{RDI}_{+3.15}$ of the sinter can be improved; however, the $T_{10 \%}$ of the sinter decreases. With continuously increasing Ore-A ratio, the oxidation atmosphere in the sintering process is weakened, which is detrimental to the generation of the SFCA, as characterized by the low melting point and good reduction property. In addition, the bonding phase SFCA in the sinter changes to the kirschsteinite and other high-melting-point silicates. Therefore, the RI of the sinter decreases, whereas the $T_{10 \%}$ and $\Delta T$ of the sinter increase.

In the case of scheme $9 \#$, an inconspicuous effect of the Australian iron ore concentrate on the $\mathrm{RDI}_{+3.15}$ and $T_{10 \%}$ of the sinter might be caused by the generation of the high-melting-point $2 \mathrm{CaO} \cdot \mathrm{SiO}_{2}$. The $2 \mathrm{CaO} \cdot \mathrm{SiO}_{2}$ in the sinter can undergo a crystal transition during cooling, leading to the formation of small cracks in the sinter. As a result, the $\mathrm{RDI}_{+3.15}$ decreases. Given the utilization of Australian iron ore concentrate and the improvement of the sinter properties, the Ore-A ratio is suggested to be controlled at approximately $6 \mathrm{wt} \%$.
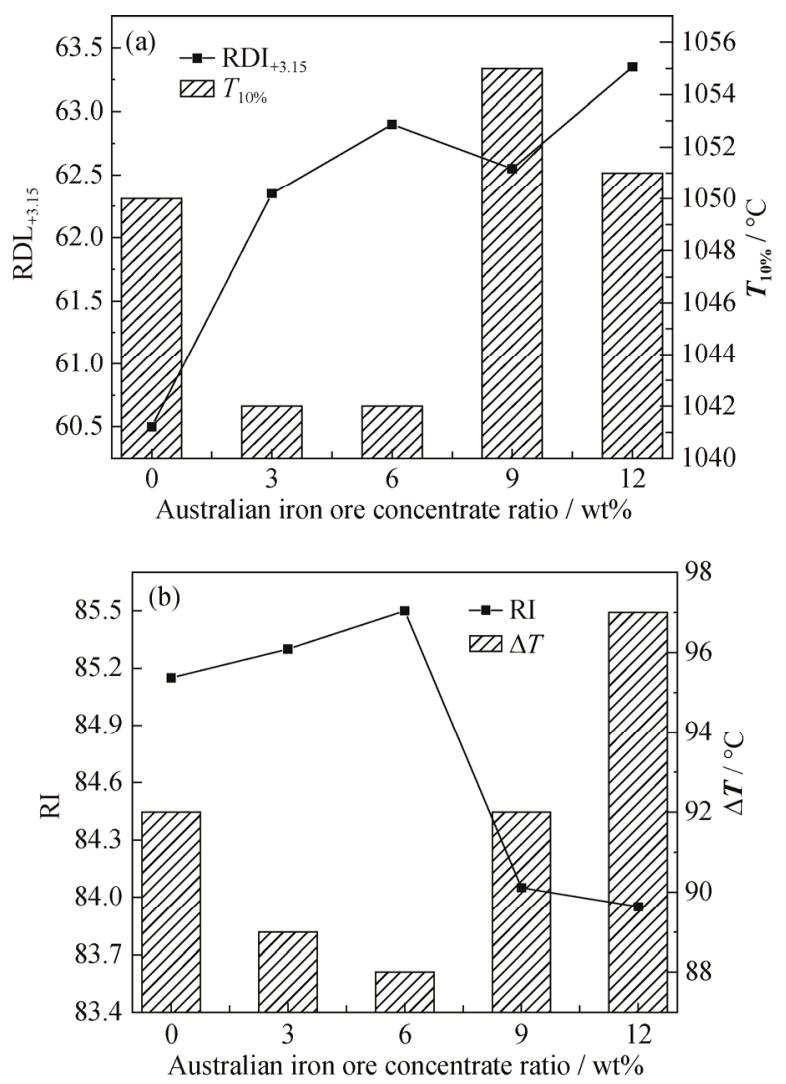

Fig. 7. (a) Effect of the Australian iron ore concentrate on the $\mathrm{RDI}_{+3.15}$ and $T_{10 \%}$; (b) effect of the Australian iron ore concentrate on the RI and $\Delta T$.

\section{Conclusions}

(1) Australian iron ore concentrate exhibits good granulation properties, strong liquid flow capability, high bonding phase strength and crystal strength, but poor assimilability. The tumbler index of sinter and the ratio of $10-40 \mathrm{~mm}$ sinter first increase and then decrease with increasing Australian iron ore concentrate ratio; however, no effect on the sinter yield is evident.

(2) As the Australian iron ore concentrate ratio increases, the mineral distribution is more even and the crystallization is more sufficient. The main bonding phase first changes from SFCA to kirschsteinite, silicate, and SFCA and then transforms to $2 \mathrm{CaO} \cdot \mathrm{SiO}_{2}$ and SFCA.

(3) The RI of the sinter first increases and then decreases with increasing Australian iron ore concentrate ratio, whereas the $\Delta T$ of the sinter exhibits the opposite behavior. Overall, with increasing Ore-A ratio, the $\mathrm{RDI}_{+3.15}$ of the sinter increases linearly and the $T_{10 \%}$ first decreases and then increases. Given the utilization of iron ore and the improvement of the sinter properties, the scheme of ore blend- 
ing is optimal when the ratio of Ore-A is $6 \mathrm{wt} \%$.

\section{Acknowledgements}

This work was financially supported by the National Basic Research Program of China (No. 2012CB720401) and the National Natural Science Foundation of China (U1260202).

Open Access This article is distributed under the terms of the Creative Commons Attribution 4.0 International License (http://creativecommons.org/licenses/by/4.0/), which permits unrestricted use, distribution, and reproduction in any medium, provided you give appropriate credit to the original author(s) and the source, provide a link to the Creative Commons license, and indicate if changes were made.

\section{References}

[1] Z.W. Peng, D. Gregurek, and C. Wenzl, Sustainability in metallurgy, JOM, 67(2015), No. 9, p. 1931.

[2] S.L. Wu, G.L. Zhang, S.G. Chen, and B. Su, Influencing factors and effects of assimilation characteristic of iron ores in sintering process, ISIJ Int., 54(2014), No. 3, p. 582.

[3] D.H. Liu, J.L. Zhang, Z.J. Liu, Y.Z. Wang, X. Xue, and J. Yan, Effects of iron sand ratios on the basic characteristics of vanadium titanium mixed ores, JOM, 68(2016), No. 9, p. 2418.

[4] J. Zhu, S.L. Wu, J.X. Fan, G.L. Zhang, and Z.G. Que, Effect of the separation of large limonite ore particles in the granulation process of sinter raw materials, ISIJ Int., 53(2013), No. 9, p. 1529.

[5] F.Z. Chen and J.B. Sun, Current development situation on technology for limonite-sintering at home and analysis on its influence factors, Angang Technol., 4(2015), No. 4, p. 8.

[6] J.J. Dong, G. Wang, Y.G. Gong, Q.G. Xue, and J.S. Wang, Effect of high alumina iron ore of gibbsite type on sintering performance, Ironmaking Steelmaking, 42(2015), No. 1, p. 30.

[7] S.L. Wu and G.L. Zhang, Liquid absorbability of iron ores and large limonite particle divided adding technology in the sintering process, Steel Res. Int., 86(2015), No. 9, p. 1014.

[8] D.H. Liu, J.L. Zhang, Z.J. Liu, K.J. Li, Y.Z. Wang, and G.W. Wang, Effects of liquid infiltration characteristics of iron ores with a high proportion of limonite on sinter strength, Metall. Res. Technol., 113(2016), No. 3, p. 301.

[9] S.L. Wu, Y.M. Dai, D. Oliveira, Y.D. Pei, J. Xu, and H.L. Han, Optimization of ore blending during sintering based on complementation of high temperature properties, J. Univ. Sci. Technol. Beijing, 32(2010), No. 6, p. 719.

[10] M. Zhou, T. Jiang, S.T. Yang, and X.X. Xue, Vanadium-titanium magnetite ore blend optimization for sinter strength based on iron ore basic sintering characteristics, Int . J. Miner. Process., 142(2010), p. 125.

[11] T. Maeda, R. Kikuchi, K. Ohno, M. Shimizu, and K. Kunitomo, Effect of particle size of iron ore and coke on granulation property of quasi-particle, ISIJ Int., 53(2013), No. 9, p. 1503.

[12] G.W. Zhang, L.J. Tong, Y. Yao, and Z.L. Li, Study on process mineralogy of Australian magnetite concentrate, China Min. Mag., 25(2016), No. 3, p. 107.

[13] Z.C. Huang, Z.G. Han, J.W. Zhou, T.Q. Jiang, and X.P. Yang, Influence of $\mathrm{MgO}$ on microstructure of fine magnetite concentrate based sinter, Iron Steel, 40(2005), No. 9, p. 16.

[14] D.Q. Zhu, T.J. Chun, J. Pan, L.M. Lu, and Z. He, Upgrading and dephosphorization of Western Australian iron ore using reduction roasting by adding sodium carbonate, Int. J. Miner. Metall. Mater., 20(2013), No. 6, p. 505.

[15] S.L. Wu, J. Zhu, J.X. Fan, G.L. Zhang, and S.G. Chen, Sintering behavior of return fines and their effective utilization method, ISIJ Int., 53(2013), No. 9, p. 1561.

[16] G.L. Zhang, S.L. Wu, S.L. Chen, J. Zhu, J.X. Fan, and B. Su, Optimization of dolomite usage in iron ore sintering process, ISIJ Int., 53(2013), No. 9, p. 1515.

[17] B. Phillips and A. Muan, Phase equilibria in the system CaO-iron oxide- $\mathrm{SiO}_{2}$ in air, J. Am. Ceram. Soc., 42(1959), No. 9 , p. 413 . 